\title{
How Do Soil Resources Affect Herbivory in Tropical Plants Along Environmental Gradients? A Test Using Contrasting Congeneric Species
}

Victor Diniz Pinto ( $\square$ vdinizpinto@gmail.com )

Universidade Federal de Vicosa https://orcid.org/0000-0002-1132-9886

Clara Cruz Vidart Badia

Universidade Federal de Vicosa

Glória Ramos Soares

Universidade Federal de Vicosa

Hildeberto Caldas Sousa

Universidade Federal de Ouro Preto - Campus Morro do Cruzeiro: Universidade Federal de Ouro Preto

Tatiana Cornelissen

Universidade Federal de Minas Gerais

Sérvio Pontes Ribeiro

Universidade Federal de Ouro Preto - Campus Morro do Cruzeiro: Universidade Federal de Ouro Preto

\section{Research Article}

Keywords: Resource availability, foliar nutrients, environmental gradients, plant functional traits

Posted Date: May 25th, 2021

DOI: https://doi.org/10.21203/rs.3.rs-539093/v1

License: (9) (i) This work is licensed under a Creative Commons Attribution 4.0 International License. Read Full License 


\section{Abstract}

Plants adapted to different habitats exhibit differences in functional traits and these characteristics are influenced by soil properties. We tested the hypothesis that soil resource availability influences the functional traits of plants, affecting therefore herbivory levels. We examined three Byrsonima plant species with different life forms that occurred across a distinct edaphic habitat along the Doce River Basin, South-eastern Brazil. We characterize habitats according to soil nutrient concentration and measured functional characteristics of crown architecture, leaf nutrients, sclerophylly, leaf area and leaf density. In addition, we evaluated how these variables influenced herbivory levels of congeneric plants. Our data have shown that species along a gradient of soil nutrients have functional characteristics influenced by habitat, which in turn affected herbivory levels. By comparing species from different life forms but within the same genus along a stress-gradient of continuous habitats, we described a corresponding gradient of plant functional traits and tissue consumption by herbivorous insects.

\section{Introduction}

Plants adapt to habitat characteristics by morphological and physiological adjustments to specific abiotic conditions (Harper 1977; Mark et al. 2001; Mello et al. 2020). Soil nutrients are amongst the most influential drivers of species distribution (Prentice et al. 1992; Rodrigues et al. 2018) and morphological trait selection (Cunningham et al. 1999; Ordoñez et al. 2009). Edaphic factors can influence plant growth (Dighton and Krumins 2004), morphology (Wand et al. 2018) and secondary chemistry (Fine et al. 2004, 2006). These morphological, physiological and/or phenological characteristics that affect growth, survival or reproduction are considered functional traits (Violle et al. 2007). Plant survival and fitness are also influenced by insect herbivory, which can be an important selective pressure (Coley and Barone 1996; Allan and Crawley 2011; Jogesh et al. 2016). Leaf damage caused by insects can impact net primary production (Zvereva and Kozlov 2014), decrease pollinator attraction (Lehtilä and Strauss 1997, Moreira et al. 2019), and reduce reproductive capacity (Strauss et al. 1996; Schiestl et al. 2014; Kozlov and Zvereva 2017). In turn, the evolutionary investment on growth or defences is a main trade-off in life history traits related to plant adaptation to cope with herbivory (Herms and Mattson 1992; Poorter et al. 2010). Plant morphologic and physical defences are amongst the most studied factors influencing herbivory levels (reviewed by Carmona et al. 2011), whereas other traits such as plant size, plant appearance and architecture have received considerably less attention in the literature. Variation in plant nutrient quality has been also suggested as an important cause of variation in herbivory levels (Mattson 1980; Johnson 2008). Usually, nutritious plants are those with high concentrations of macronutrients, such as nitrogen - which is essential for insect survival and reproduction (Raubenheimer and Simpson 2003; Roeder and Behmer 2014) - and are likely to occur more frequently on fertile soils.

Host plant structural complexity (Spawton and Wetzel 2015) and leaf nutritional quality (MaldonadoLópez et al., 2014) affect the quantity and quality of available food resources that in turn might directly affect herbivory levels (Campos et al. 2006; Schlinkert et al. 2015). According to the plant architecture hypothesis (Lawton 1983), plants with larger life forms (such as trees) have a more complex architecture 
due to the higher number of branches and leaves. Consequently, they may harbour greater richness and abundance of insects with more sites for feeding and oviposition. Previous studies have reported positive effects of plant size on herbivore species richness and abundance (Ribeiro et al. 2005; Campos et al. 2006; Neves et al. 2013; Zvereva et al. 2014), or in the distribution of herbivory within plants (Ribeiro and Basset 2007; Pereira et al. 2017; Boaventura et al. 2018). In fact, global herbivory patterns have shown higher levels of insect damage on trees compared to shrubs (Kozlov et al. 2015).

Plant life forms occurring in fertile soils are capable to cope with some level of herbivory, without the associated negative impacts in fitness or growth (Coley et al. 1985), mainly due to low energy cost for tissue reposition, short lifespan and high return rates (Zhang et al. 2016). Life forms - like shrubs - that are adapted to respond to low resource availability, such as those conditions found in poor soils, need to invest in effective defences against herbivory, as each leaf produced implies in a high-energy cost (Coley et al. 1985; Wright et al. 2007). Plants adapted to unfertile habitats, on the other hand, may exhibit the greatest investment in chemical defences compared to those from nutrient-rich soils, given the need to grow slower and avoid damage to each valuable tissue (Herms and Mattson 1992; Fine et al. 2006; Ribeiro and Brown 2006; Poorter et al. 2010). Additionally, these plants exhibit a high C/N ratio and, thus, might have more sclerophyllous leaves than related species found on richer soils (Harbone 1980; Bryant et al. 1983, Ordoñez et al. 2009). In fact, there is a strong relationship between soil nutrient availability, plant life forms and growth strategies (Grime 1977; Gong and Gao 2019), and all these factors combined affect herbivory levels experienced by plants.

The relationship among soil nutrient availability, plant life forms and growth strategies can be investigated on congeneric species that occupy contrasting habitats. From a tropical lowland forest towards a high altitudinal grassland, there is a continuous, but remarkable change in soil conditions (Clark et al. 1999). Tropical lowlands are warmer and have high availability of light and water, accelerating decomposition and making nutrients more readily available, providing greater heterogeneity compared to any adjacent montane ecosystems from a similar geological background. There are several examples of congeneric species that occupy these contrasting habitats, providing excellent systems to study the relationships between life forms and plant characteristics while controlling for phylogeny (Silvertown and Dodd 1996; Sultan 2000).

The present study investigated the effects of soil nutritional quality on functional characteristics and consequently on herbivory levels of congeneric plants of different life forms across a gradient of edaphic conditions. These are closely related species (all belonging to the genus Byrsonima sp. Rich. ex Kunth Malpighiaceae) occurring along a gradient of decreasing soil resource availability, from a semi-deciduous tropical lowland forest towards two montane physiognomies of highlands grasslands (campo rupestre sensu Silveira et al. 2016). We tested the hypothesis that soil nutrient availability affects the functional characteristics and consequently the herbivory levels of the different plant life forms. We proposed that tree species that occupy forest habitats in soils with higher nutrient availability would exhibit complex architecture, higher nutritional quality, less sclerophylly and higher levels of herbivory than structurally simpler shrub and sub-shrub species occurring in poorer habitats along the gradient. 


\section{Material And Methods \\ Study sites}

The study was carried out in sites located in the Doce River Basin, in Minas Gerais State, Brazil, in the upper and mid-basin regions (Fig. 1). This is an $83,400-\mathrm{km}^{2}$ basin, the third largest in the State. We sampled in three State Parks: Rio Doce (PERD), Itacolomi (PEIT), and Serra de Ouro Branco (PESOB). The PERD ( $19^{\circ} 45^{\prime} \mathrm{S} 42^{\circ} 38^{\prime} \mathrm{W}$ ) represents the largest remnant of semi-deciduous Atlantic Forest of Minas Gerais with an area of approximately 36,000 ha and altitude ranging between $200-500 \mathrm{~m}$. The climate is tropical seasonal Aw according to Köppen (Alvares et al. 2014). Seasons are well defined, with wet season lasting for 7-8 months and dry season drought for 4-5 months, with average rainfall of 1,500 $\mathrm{mm}$ per year (Silva 2001).

The PEIT $\left(20^{\circ} 22^{\prime} 30^{\prime \prime} \mathrm{S}\right.$ and $\left.43^{\circ} 22^{\prime} 30^{\prime \prime} \mathrm{W}\right)$ is located in the southern portion of the Espinhaço Range in the state of Minas Gerais. It has an approximate area of 7,000 ha, with altitude varying between $1400-1772 \mathrm{~m}$ a.s.I. The predominant vegetation communities are distributed in quartzitic and ferruginous rock fields, formations of campo rupestre, montane forest and natural monodominant stands of Eremanthus erythropappus (Asteraceae), a pioneer tree (Fujaco et al. 2010). Average annual rainfall is $1,500 \mathrm{~mm}$, summers are hot, rainy and last approximately 8 months and the dry season, lasts between 3 and 4 months. The climate is tropical humid type Cwb following the Köppen classification (Alvares et al. 2014).

The PESOB $\left(20^{\circ} 31^{\prime} \mathrm{S}, 43^{\circ} 41^{\prime} \mathrm{W}\right)$ is situated in the southern boundary of the Espinhaço Range and has an approximate area of 7,500 ha. The altitude in the Park varies between 800 and 1,510 m a.s.I and vegetation is characterized by campo rupestre in highlands and, in the lower portions, by riparian forests and forest patches embedded inside a grassland ecosystem (Instituto Estadual de Florestas, 2015). The climate is tropical humid type Cwb following the Köppen classification and has similar annual average rainfall and seasons as PEIT (Alvares et al. 2014).

Considering the three areas sampled, this study was conducted along a gradient of resource availability, from a habitat of poor, shallow and sandy soils towards deep and nutrient-rich soils.

\section{Plant species}

The genus Byrsonima is one of the most important genera of the Malpighiaceae due to its large number of species, with 135 described species restricted to tropical and subtropical regions (Anderson 1977; Davis and Anderson 2010). The genus occurs throughout the Neotropical regions and in Brazil in the phytogeographical domains of the Amazon, Cerrado, Caatinga, Atlantic Forest and Pantanal (Mamede and Francener 2015). Byrsonima sericea DC. is a tree species with wide distribution (Mamede and Francener 2015). In our study system, we sampled this species in the forest habitat of the PERD, specifically in ecotonal habitats between forests and natural lakes, where its crowns grow branched in search of light. Byrsonima variabilis A. Juss. is a shrub species, endemic to the Brazilian mountains highlands (Mamede and Francener 2015). This species population in the PEIT was sampled in habitats 
of rocky outcrop in campo rupestre. Their crowns have cylindrical shapes with branches not far apart and small internodes. Byrsonima subterranea Brade \& Markgr. is a sub-shrub species that occurs in campo rupestre Cerrado (latu sensu) and Amazonian Savanna (Mamede and Francener 2015). The individuals of this species in PESOB were studied in campo rupestre, in sandy quartzite soil, called white sand soil. They grow with subterranean stems and only the leaves and reproductive parts are aerial, hence not forming a typical crown.

\section{Sampling design}

Each species of Byrsonima was treated as a life form. We sampled three populations of $B$. sericea (tree) in PERD, three populations of $B$. variabilis (shrub) in PEIT and three populations of $B$. subterranea (subshrub) in PSOB. In each population we sampled 15 individuals, totalling nine populations and 135 individuals. All data were collected between January and March 2016, at the end of the rainy season, with the aim to quantify the accumulated herbivory during the last rainy season.

\section{Soil nutrients}

For soil characterization, one sample was collected at every three individual plants, totalling five samples per population. We chose to collect the soil at $10 \mathrm{~cm}$ depth due to its relationship to vegetation characteristics, as suggested by Ruggiero et al. (2002). The soil parameters analysed were $\mathrm{pH}$, organic matter $(O M)$, and concentrations of nitrogen $(N)$, phosphorus $(P)$, potassium $(K)$, calcium $(C a)$, magnesium (Mg), and aluminium (Al). All nutrient analyses were performed according to Defelipo and Ribeiro (1997), Embrapa (1999), and Raij et al. (2001), at the Laboratory of Plant Analysis of the Department of Soils of the Agricultural Sciences Centre of the Federal University of Viçosa, Minas Gerais.

\section{Functional traits and Herbivory}

Plant Architecture

Due to structural differences among species, we adjusted the architectural complexity measurements for the three species, allowing for direct comparisons between their different life forms. The following parameters were measured: total height $(\mathrm{cm})$, trunk diameter below the first branch $(\mathrm{cm})$, number of growth units, and mean leaf number (see Pérez-Harguindeguy et al. 2013). Growth units were defined as the set of terminal branches of each ramification from which the leaves originated (see Bell et al. 1999). In each individual plant we counted all the growth units.

\section{Leaf nutrients and sclerophylly}

To quantify leaf nutrient content, a set of 20 mature, fully expanded leaves of each individual were collected and oven dried to quantify $\mathrm{N}, \mathrm{P}, \mathrm{K}, \mathrm{Ca}$ and $\mathrm{Mg}$ content. Leaf sclerophylly was measured as leaf thickness (Choong et al. 1992), using a Digimess digital micrometer with an accuracy of $0.001 \mathrm{~mm}$. This method is correlated with other methods of measuring sclerophylly, such as dry weight, fibre content and protein content (Choong et al. 1992; Pérez-Harguindeguy et al. 2013). 
Leaf samples were taken using a random delimited volume within each crown. For such, we used three hollow cubes, thus combining the canopy cylinder method (Ribeiro and Basset 2007) with the subplot frame model (Shaw et al. 2006) to sample leaves and quantify herbivory levels. This method was selected to avoid biased sampling, commonly documented in herbivory studies (Kozlov et al. 2015). The cube volume was chosen to control differences in the size of each species and to fit the approximately area occupied by the foliage of a growth unit. In $B$. variabilis, three cubes with $20 \mathrm{~cm}$ length, $20 \mathrm{~cm}$ width, and $20 \mathrm{~cm}$ height were used, with a total volume of $0.06 \mathrm{~m}^{3}$. In $B$. sericea three cubes, $30 \mathrm{~cm}$ long, $30 \mathrm{~cm}$ wide and $30 \mathrm{~cm}$ high, with a total volume of $0.09 \mathrm{~m}^{3}$ were used for sampling. Each cube was positioned in three different branches (chosen at a distance of 5 meters from the plant to avoid bias) of the crown of each individual and all leaves inside the cube were collected (Fig. 2). Due to its small size, the cube was not used in $B$. subterranea and all leaves of each plant were collected.

To quantify herbivory, leaf density and leaf area, all mature and fully expanded leaves per individual (collected as described above) were counted and digitized. Leaf density was considered as the total number of leaves collected. Average leaf area and the percentage of leaf damage by chewing insects (in $\mathrm{cm}^{2}$ ) were calculated through Image J 1.6 .0 software.

\section{Statistical analyses}

We tested whether each site differed for soil nutrients using an Analyses of Variance (ANOVA) for each element, considering each environment as a level of a simple fixed factor. The functional traits were explored to collinearity, and in cases when variables were positively correlated (Pearson $>0.70$ ), only the variable with the greatest biological meaning for the hypotheses tested was used. Normality was tested for the models constructed based on error distribution. Non-significant explanatory variables were eliminated from analyses to obtain an adequate minimum model (Crawley 2013).

To test the hypothesis that the functional traits and herbivory of plants responded to the resource availability gradient, a multiple regression analysis was performed. The functional traits and herbivory were used with response variables and soil nutrients with explanatory variable. To test whether functional traits affect herbivory levels in Byrsonima sp., an analysis of covariance (ANCOVA) was performed with error distribution adjusted for quasibinomial, with leaf area weighted by leaf size. Species and environment were considered as fixed factors, populations as nested randomized blocks, and architectural measures, leaf nutrients, and sclerophylly as covariates. The average leaf area lost by each individual was the response variable.

Statistical analyses were performed in R Environment v. 3.2.0 (R Development Core Team 2015) and ANOVA, multiple regression analysis and ANCOVA were completed using generalized linear models (GLM).

\section{Results}




\section{Soil nutrients}

The forest was the habitat with the highest concentration of Nitrogen $\left(F_{2,42}=16.87, P<0.001\right)$, Phosphorus $\left(F_{2,42}=28.62, P<0.001\right)$, Magnesium $\left(F_{2,42}=7.64, P=0.001\right)$ and Organic Matter $\left(F_{2,42}=\right.$ 11.68; $P<0.001$ ), followed by rocky outcrop (PEIT) and white sand soil (PSOB), respectively (Fig. 3). The white sand soil habitat diverged from the other environments due to higher concentrations of Aluminium $\left(F_{2,42}=3.88, P<0.05\right)$ (Fig. 3E). The amounts of Potassium $\left(F_{2,42}=0.6, P=0.55\right)$ and Calcium $\left(F_{2,42}=\right.$ $0.35, P=0.7)$ did not differ significantly among habitats.

\section{Functional traits}

The three species differed markedly in functional traits (Table 1). Byrsonima sericea is a mid-size tree, 5 metres tall, its growth units were well-spaced, long, and exhibited a high density of leaves $(482 \pm 218.5$ leaves). Byrsonima variabilis is a 1.5-m high shrub with a round canopy, growth units short and close to each other, and high leaf density (300 \pm 134.9 leaves). Byrsonima subterranea is a low shrub $(0.28 \mathrm{~cm})$, with the leaves near the ground and very individualized and short growth units. In this species, the entire stem remains below ground and only a small part of the terminal branch - from which few leaves emerge (20 \pm 15.9 leaves) - is exposed aboveground. 
Table 1

Habitat summary, functional traits and herbivory levels (mean \pm SE) of three Byrsonima species. Different letters indicate statistical differences between the variables.

\begin{tabular}{|llll|}
\hline & Byrsonima sericea & Byrsonima variabilis & Byrsonima subterranea \\
\hline Ecoregion & Atlantic Forest & Campo rupestre & Campo rupestre \\
\hline Habitat & Forest & Rocky Outcrop & White Sand \\
\hline Park & PERD & PEIT & PSOB \\
\hline Life history & Tree & Shrub & Sub shrub \\
\hline Height (cm) & $5.22 \pm 1.25^{\mathrm{a}}$ & $1.51 \pm 0.42^{\mathrm{b}}$ & $0.28 \pm 0.04^{\mathrm{c}}$ \\
\hline Trunk diameter (cm) & $59.81 \pm 29.66^{\mathrm{a}}$ & $27.49 \pm 13.45^{\mathrm{b}}$ & $8.81 \pm 3.07^{\mathrm{c}}$ \\
\hline Growth unit (un) & $52.2 \pm 22.09^{\mathrm{a}}$ & $21.88 \pm 4.48^{\mathrm{b}}$ & $6.04 \pm 3.72^{\mathrm{c}}$ \\
\hline Leaf density $(\mathrm{un})$ & $482 \pm 218.48^{\mathrm{a}}$ & $300 \pm 134.92^{\mathrm{a}}$ & $20 \pm 15.93^{\mathrm{b}}$ \\
\hline Nitrogen $(\mathrm{dag} / \mathrm{kg})$ & $1.746 \pm 0.213^{\mathrm{a}}$ & $1.352 \pm 0.162^{\mathrm{b}}$ & $1.034 \pm 0.097^{\mathrm{c}}$ \\
\hline Potassium $(\mathrm{dag} / \mathrm{kg})$ & $0.339 \pm 0.085^{\mathrm{a}}$ & $0.313 \pm 0.054^{\mathrm{a}}$ & $0.647 \pm 0.130^{\mathrm{b}}$ \\
\hline Calcium (dag/kg) & $1.313 \pm 0.372^{\mathrm{a}}$ & $0.879 \pm 0.351^{\mathrm{b}}$ & $1.267 \pm 0.377^{\mathrm{a}}$ \\
\hline Magnesium (dag/kg) & $0.222 \pm 0.047^{\mathrm{a}}$ & $0.090 \pm 0.028^{\mathrm{b}}$ & $0.146 \pm 0.043^{\mathrm{c}}$ \\
\hline Sclerophylly (mm) & $0.266 \pm 0.017^{\mathrm{a}}$ & $0.471 \pm 0.033^{\mathrm{b}}$ & $0.549 \pm 0.101^{\mathrm{c}}$ \\
\hline Herbivory $(\%)$ & $5.58 \pm 3.86^{\mathrm{a}}$ & $3.50 \pm 1.80^{\mathrm{b}}$ & $2.97 \pm 2.33^{\mathrm{b}}$ \\
\hline
\end{tabular}

A total of 36,050 leaves distributed among the three Byrsonima species were sampled. Byrsonima sericea was the species with the greatest architectural complexity, being the taller $\left(F_{2,132}=512.28, P<0.001\right)$, with larger trunk diameter $\left(F_{2,132}=244.47, P<0.001\right)$, greater number of growth units $\left(F_{2,132}=69.34, P<\right.$ $0.001)$, and leaf density $\left(F_{2,132}=110.19, P<0.001\right)$, followed by $B$. variabilis and $B$. subterranea (Table 1$)$. As plant height, trunk diameter, and growth units were highly correlated ( $r$ Pearson $>0.70$ ), we opted to use only leaf density and growth unit variables for herbivory analyses.

Leaf nitrogen content was higher in tree followed by shrub and sub-shrub, respectively $\left(F_{2,132}=210.54 ; P\right.$ $<0.001)$. Potassium content was higher in $B$. subterranea $\left(F_{2,132}=171,07 ; P<0.001\right)$ than in $B$. sericea and $B$. variabilis, which were similar. For Calcium, the values were similar in $B$. sericea and $B$. subterranea and lower in $B$. variabilis $\left(F_{2,132}=18.96 ; P<0.001\right)$. Magnesium concentration was highest in the leaves of $B$. sericea, followed by $B$. subterranea and $B$. variabilis $\left(\mathrm{F}_{2,132}=115,98 ; P<0.001\right)$. Sclerophylly differed 
significantly amongst the three species $\left(F_{2,132}=244,27 ; P<0.001\right)$, with sub-shrub being the most sclerophyllous, followed by shrub and tree, respectively (Fig. 4).

\section{Herbivory}

Herbivory was higher in tree species than in the others two growth forms $\left(F_{2,132}=13.62 ; \mathrm{P}<0.001\right)$ with levels of herbivory around $5 \%(5.58 \pm 3.86 \%)$ for trees and around $3 \%$ for shrubs and sub shrubs ( $B$. variabilis $3.50 \pm 1.80 \%$ and $B$. subterranea $2.97 \pm 2.33 \%$ ) (Fig. $4 \mathrm{E}$ ). Regardless of species, the percentage of leaf area lost was positively related to Nitrogen $\left(F_{1}, 131=16.58 ; P<0.001\right)$ (Fig. 5$)$ and Potassium leaf content $\left(F_{1,130}=5.17, P<0.02\right)$. We also found a significant interaction between growth units and species, i.e., herbivory increased significantly with the number of growth units for $B$. variabilis and $B$. subterranea, but not for $B$. sericea $\left(F_{1,132}=35.94 ; P<0.001\right)$. However, there was no relationship between sclerophylly and herbivory levels $\left(F_{1,129}=16.58 ; P<0.001\right)$.

\section{Effect of resource availability on architectural complexity, morphological characteristics and herbivory}

Plant height was positively related to soil nitrogen $\left(F_{1,43}=74.82 ; P<0.001\right)$ (Fig. $\left.4 A\right)$, soil phosphorus $\left(F_{1,42}=45.22, P<0.001\right)$, soil potassium $\left(F_{1,41}=10.60 ; P=0.002\right)$ and soil magnesium $\left(F_{1,40}=7.45 ; P<\right.$ 0.005). We also found a positive relationship between growth units and soil nitrogen $\left(F_{1,43}=13.03 ; P<\right.$ $0.001)$ and soil phosphorus $\left(F_{1,42}=16.34, P<0.001\right)$ (Fig. 4B).

Leaf density increased with increased availability of nitrogen $\left(F_{1,43}=19.22 ; \mathrm{P}<0.001\right)$ and phosphorus $\left(F_{1,42}=9.1, P<0.01\right)$ in the soil. Sclerophylly, on the other hand, was negatively affected by the amounts of nitrogen $\left(F_{1,43}=42.77 ; P<0.001\right)$ (Fig. $\left.4 C\right)$, phosphorus $\left(F_{1,42}=26.39 ; P<0.001\right)$ and magnesium $\left(F_{1,41}=6.47 ; P=0.01\right)$ in the soil. Herbivory level increased with increased soil phosphorus $\left(F_{1,43}=15.04\right.$; $P<0.001)$ (Fig. 4D) and potassium $\left(F_{1,42}=8.88 ; P<0.01\right)$.

\section{Discussion}

We found strong evidence that the variation of functional characteristics is influenced by soil nutrient content and that, consequently, these functional characteristics affect herbivory levels experienced by plants. In the present study, the average rates of foliar consumption by insect herbivores were low compared to the global patterns that are around 4.5\% (Kozlov et al. 2015), with trees exhibiting the highest levels of herbivory. The tree species here studied occurred in a high-productivity forest habitat and with the highest nutrient content in its leaves. The shrub and sub-shrub life forms, on the other hand, occupied oligotrophic habitats and were less consumed by herbivorous insects. These results indicate different strategies of resource use and acquisition (Wright et al. 2004). Tree species have characteristics (such as many growth units and high leaf nutrient content) associated with the ability to quickly capture light and nutrients (Ordoñez et al. 2009; Poorter et al. 2011; Reich 2014). On the other hand, the shrub and 
sub-shrub species exhibit a conservation strategy, as they have functional characteristics (like sclerophylly) linked to tissue protection (Díaz et al. 2004; Reich 2014). This relationship among acquisitive and conservative strategies can be mediated by soil nutrients (Hernández-Vargas et al. 2019). Our results indicate that soils with higher concentration of macronutrients and organic matter (i.e., more productive soils) positively affect height, growth units, leaf nutrient concentration and leaf density. In contrast, these richer soils lower the levels of plant sclerophylly. Soils with high concentrations of aluminium, on the other hand, were associated to increased sclerophylly. Consequently, the functional characteristics of growth units, leaf nutrient concentration and leaf density positively affected herbivory levels, whereas sclerophylly was inversely related to the amount of tissue removed by insects. Similar results were found by Lynn and Fridley (2019) suggesting an effect of soil on functional characteristics and consequently on plant herbivory.

The three studied species of Byrsonima occurred along a soil nutritional gradient, from the lowland forest - the most fertile habitat - to the campo rupestre, a comparably poorer habitat. Life form and architecture here described are probably consequences of adaptive demands linked to abiotic environmental conditions, as suggested by Grime (1977) and Crawley (1997). The number of growth units, leaf density, and higher leaf nutrient concentration in tree species are typical characteristics of plants from productive environments (Wright et al. 2004). The smaller number of growth units of shrubs and sub-shrubs may be related to a trade-off in biomass investment among resources for growth and protection of plant tissues. Both species occurred as a shrub or sub-shrub life forms and are highly sclerophyllous, compatible with what is expected for species occurring in the campo rupestre (Giulietti et al. 1997; Ribeiro et al. 1999; Negreiros et al. 2014; Silveira et al. 2015). Therefore, the functional traits of the plants respond to the gradient of resource availability of the habitats, and consequently herbivory levels follow this gradient, supporting our hypothesis.

Our results also corroborate the Resource Availability Hypothesis (Coley et al. 1985) and the Plant Architecture Hypothesis - PAH (Lawton 1983). The crown architecture (measured here by the number of growth units) has a strong relationship with herbivory levels (Zvereva et al. 2014; Pereira et al. 2017). Some previous studies have shown, for example, that the size of the plant positively influences the availability of niche for the survival and feeding of herbivores (Hannunen 2002; Campos et al. 2006; Randlkofer et al. 2009). In addition, our results are in line with the Plant Apparency Hypothesis, which predicts that larger plants are more likely to be found by herbivorous insects (Feeny 1976; Rhoades and Cates 1976, Smilanich et al. 2016). Our data corroborate other studies that found the positive effect of apparency (in our study measured by the number of growth units) and herbivory (Castagneyrol et al., 2013; Smilanich et al. 2016). Our results, however, indicated a positive relationship between number of growth units and herbivory only for shrubs compared to sub-shrubs. This relationship between apparency and levels of herbivory can be even more important in open environments, such as the rupestrian field, where visible plants are even more easily found by herbivorous insects.

Leaf nutrient content also influenced positively herbivory levels in Byrsonima species, as previously reported (e.g., Casotti and Bradley 1991; Meloni et al. 2012; Silva et al. 2015). Soil nutrient availability and 
leaf nutritional content have been related to the production of simple and low-cost tissues, which facilitates insect feeding (Coley 1983; Coley et al. 1985; Price 1991), and may clearly affect plant selection by insects (Mattson 1980). We did not find a relationship between sclerophylly and herbivory levels, contrary to other studies (e.g., Pennings and Paul 1992; Ribeiro and Basset 2007; Malishev and Sanson 2015), although sclerophylly in tree species was the lowest. However, Byrsonima shrub and sub shrubs exhibited high sclerophylly, as commonly expected for species that occur in the campo rupestre (Negreiros et al. 2014). We attributed this result to the fact that the campo rupestre is a geologically old biome, accumulating 65 million years of species adaptation and speciation (Silveira et al. 2016), where high sclerophylly is expected to be a default trait (Ribeiro et al. 1999). It is likely that herbivorous species have had time to evolve strategies to deal with sclerophylly in these habitats. Similar results were reported by Meloni et al. (2012), indicating that concentrations of defensive compounds in Cerrado plants did not inhibit herbivory, probably due to a very long period for adaptation. Therefore, data suggest that as herbivores have already overcome the barrier of leaf toughness, they can choose the most nutritious plants, regardless of the level of sclerophylly.

Our data have shown that species along a gradient of soil nutrients have functional characteristics influenced by habitat, ultimately affecting herbivory levels. Differences in herbivory levels amongst species of distinct life forms can be explained by functional characteristics, which are an adaptive response to habitat type. By comparing species from different life forms but within the same genus, along a stress-gradient of continuous habitats, we described a corresponding gradient of plant tissue consumption by herbivorous insects. The confounding effects between habitat resource availability and plant life form was coherent with theoretical predictions. Data among species, however, is suggestive of evolutionary filters that may further constrain herbivores in high-altitude grasslands.

\section{Declarations}

\section{Funding}

This research was supported by the Fundação de Amparo à Pesquisa do Estado de Minas Gerais (APQ03035-18), and the Long-Term Ecological Research project (PELD) (15/2016 CNPq).

\section{Acknowledgments}

We thank the Instituto Estadual de Floresta (IEF-MG) for logistic support at collection sites and Bárbara Dolabela for carefully reading and reviewing the first draft of the manuscript. Victor D. Pinto thanks the Coordenação de Aperfeiçoamento de Pessoal de Nível Superior for funding (financial code 001). Sérvio P. Ribeiro and T. Cornelissen are CNPq granted researchers (304024/2015-5 and 313007/2020-9).

\section{References}


1. Allan E, Crawley MJ (2011) Contrasting effects of insect and molluscan herbivores on plant diversity in a long-term field experiment. Ecol Lett 14:1246-1253. doi:10.1111/j.1461-0248.2011.01694.x

2. Alvares CA, Stape JL, Sentelhas PC, Golçalves JLM, Sparovek G (2014) Koppen's climate classification map for Brazil. Meteorol Z 22:711-728. doi:10.1127/0941-2948/2013/0507

3. Anderson WR (1977) Byrsonimoideae, a new subfamily of the Malpighiaceae. Leandra 7:5-18

4. Armbruster WS (2014) Multiple origins of serpentine-soil endemism explained by preexisting tolerance of open habitats. PNAS 111:14968-14969. doi:10.1127/0941-2948/2013/0507

5. Bell AD, Bell A, Dines TD (1999) Branch construction and bud defence status at the canopy surface of a West African rainforest. Biol J Lin Soc 66:481-499. doi:10.1111/j.1095-8312.1999.tb01922.x

6. Boaventura MG, Pereira CC, Cornelissen T (2018) Plant architecture influences gall abundance in a tropical montane plant species. Acta Botanica Brasilica 32:670-674. doi:10.1590/0102$33062018 \mathrm{abb} 0038$

7. Bryant JP, Chapin FS, Klein DR (1983) Carbon/nutrient balance of boreal plants in relation to vertebrate herbivory. Oikos 40:357368. doi:10.2307/3544308

8. Campos RI, Vasconcelos HL, Ribeiro SP, Neves FS, Soares JP (2006) Relationship between tree size and insect assemblages associated with Anadenanthera macrocarpa. Ecography 29:442-450. doi:10.1111/j.2006.0906-7590.04520.x

9. Carmona D, Lajeunesse MJ, Johnson MJT (2011) Plant traits that predict resistance to herbivores. Funct Ecol 25:358-367. doi:10.1111/j.1365-2435.2010.01794.x

10. Casotti G, Bradley JS (1991) Leaf nitrogen and its effects on the rate of herbivory on selected eucalypts in the jarrah forest. For Ecol Manage 41:167-177. doi:10.1016/0378-1127(91)90101-Z

11. Choong MF, Lucas PW, Ong JSY, Pereira B, Tan HTW, Turner IM (1992) Leaf fracture toughness and sclerophylly: their correlations and ecological implications. New Phytol 121:597-610. doi:10.1111/j.1469-8137.1992.tb01131.x

12. Clark DB, Palmer MW, Clark DA (1999) Edaphic factors and the landscape-scale distributions of tropical rain forest trees. Ecology 80:2662-2675. doi:10.1890/0012-9658

13. Coley PD (1983) Herbivory and defensive characteristics of tree species in a Lowland Tropical Forest. Ecol Monogr 55:209-234. doi:10.2307/1942495

14. Coley PD, Barone JA (1996) Herbivory and plant defenses in tropical forests. Annual Review of Ecology Systematics 2:305-335. doi:10.1146/annurev.ecolsys.27.1.305

15. Coley PD, Bryant JP, Chapin FS (1985) Resource availability and plant antiherbivore defense. Science 230:895-899. doi:10.1126/science.230.4728.895

16. Crawley MJ (1997) Plant Ecology. Blackwell, London

17. Crawley MJ (2013) The R book. John Wiley \& Sons

18. Cunningham SA, Summerhayes B, Westoby M (1999) Evolutionary divergences in leaf structure and chemistry, comparing rainfall and soil nutrient gradients. Ecology 69:569-588. doi:10.2307/2657231 
19. Davis CC, Anderson WR (2010) A complete generic phylogeny of Malpighiaceae inferred from nucleotide sequence data and morphology. Am J Bot 97:2031-2048. doi:10.3732/ajb.1000146

20. Defelipo BV, Ribeiro AC (1997) Análise química do solo (metodologia). Editora Viçosa, Viçosa

21. Empresa Brasileira de Pesquisa Agropecuária (EMBRAPA), Centro Nacional de Pesquisa de Solos (1999) Manual de análises químicas de solos, plantas e fertilizantes. Brasília

22. Feeny P (1976) Plant apparency and chemical defense. In: Wallace JW, MansellRL (eds) Biochemical interactions between plants and insects. Plenum, New York, pp 1-40

23. Fine PV, Mesones I, Coley PD (2004) Herbivores Promote Habitat Specialization by Trees in Amazonian Forests. Science 305:663-665. doi:10.1126/science.1098982

24. Fine PV, Miller ZJ, Mesones I, Irazuzta S, Stevens MH, Sääksjärvi I, Schultz JC, Coley PD (2006) The growth-defense trade-off and habitat specialization by plants in amazonian forests. Ecology 87:150-162. doi:10.1890/0012-9658

25. Fujaco MAG, Leite MGP, Messias MCTB (2010) Análise multitemporal das mudanças no uso e ocupação do Parque Estadual do Itacolomi (MG) através de técnicas de geoprocessamento. Revista Escola de Minas 63:695-701

26. Gong H, Gao J (2019) Soil and climatic drivers of plant SLA (specific leaf area). Global Ecology Conservation 20:1-7. doi:10.1016/j.gecco.2019.e00696

27. Grime JP (1977) Evidence for the existence of three primary strategies in plants and its relevance to ecological and evolutionary theory. Am Nat 111:1169-1194

28. Hannunen S (2002) Vegetation architecture and redistribution of insects moving on the plant surface. Ecol Model 155(2-3):149-157. doi:10.1016/s0304-3800(02)00125-4

29. Harbone JB (1980) Plant phenolics. In: Bell EA, Charlwood BV (eds) Encyclopedia of Plant Physiology. Springer, Berlim, pp 329-402

30. Harper JL (1977) The Population Biology of Plants. Academic Press: California

31. Herms DA, Mattson WJ (1992) The dilemma of plants: To grow or defend. Q Rev Biol 67:283-335

32. Instituto Estadual de Florestas (2015) O Parque Estadual Serra de Ouro Branco. Available from URL: http://www.ief.mg.gov.br/component/content/article/1411

33. Jogesh T, Overson RP, Raguso RA, Skogen KA (2016) Herbivory as an important selective force in the evolution of floral traits and pollinator shifts. Ann Bot 9:1-15. doi:10.1093/aobpla/plw088

34. Johnson MTJ (2008) Bottom-up effects of plant genotype on aphids, ants, and predators. Ecology 89:145-154. doi:10.1890/07-0395.1

35. Kozlov MV, Lanta V, Zverev V, Zvereva EL (2015) Global patterns in background losses of woody plant foliage to insects. Glob Ecol Biogeogr 24:1126-1135. doi:10.1111/geb.12347

36. Lawton JH (1983) Plant architecture and the diversity of phytophagous insects. Annu Rev Entomol 28:23-29. doi:10.1146/annurev.en.28.010183.000323

37. Lehtilä K, Strauss SY (1997) Leaf damage by herbivores affects attractiveness to pollinators in wild radish, Raphanus raphanistrum. Oikos 111:396-403. doi:10.1007/s004420050251 
38. Maldonado-López Y, Cuevas-Reys P, Sánchez-Montoya G, Oyama K, Quesada M (2014) Growth, plant quality and leaf damage patterns in a dioecious tree species: is gender important? Arthropod-plant interactions 8:241-251. doi:

39. Malishev M, Sanson GD (2015) Leaf mechanics and herbivory defence: How tough tissue along the leaf body deters growing insect herbivores. Austral Ecol 40:300-308. doi:10.1111/aec.12214

40. Mamede MCH, Francener A (2015) Byrsonima: in Lista de Espécies da Flora do Brasil. Jardim Botânico do Rio de Janeiro. Available from URL:

http://floradobrasil.jbrj.gov.br/jabot/floradobrasil/FB8827. doi: 10.1590/2175-7860201566411

41. Mark AF, Dickinson KJM, Allen J, Smith R, West CJ (2001) Vegetation patterns, plant distribution and life forms across the alpine zone in southern Tierra del Fuego, Argentina. Austral Ecol 26:423-440. doi:10.1046/j.1442-9993.2001.01127.x

42. Marquis RJ (2004) Herbivores rule. Science 30:619-621. doi:10.1126/science.1101848

43. Mattson WJ (1980) Herbivory in relation to plant nitrogen content. Annu Rev Ecol Syst 11:119-161. doi:10.1146/annurev.es.11.110180.001003

44. Mello FNA, Estrada-Villegas SDM, Schnitzer SA (2020) Can Functional Traits Explain Plant Coexistence? A Case Study with Tropical Lianas and Trees. Diversity 12:397. doi:10.3390/d12100397

45. Meloni F, Lopes NP, Varanda EM (2012) The relationship between leaf nitrogen, nitrogen metabolites and herbivory in two species of Nyctaginaceae from the Brazilian Cerrado. Environ Exp Bot 75:268276. doi:10.1016/j.envexpbot.2011.07.010

46. Moreira X, Castagneyrol B, Abdala-Roberts L, Traveset A (2019) A meta-analysis of herbivore effects on plant attractiveness to pollinators. Ecology 100:1-8. doi:10.1002/ecy.2707

47. Negreiros D, Stradic SL, Fernandes GW, Rennó HC (2014) CSR analysis of plant functional types in highly diverse tropical grasslands of harsh environments. Plant Ecol 388:215-379. doi: 10.1007/sl 1258-014-0302-6

48. Neves FS, Sperber CF, Campos RI, Ribeiro SP (2013) Contrasting effects of sampling scale on insect herbivores distribution in response to canopy structure. Rev Biol Trop 61:125-137. doi:10.15517/rbt.v61i1.10894

49. Ordonez JC, Bodegom PM, Witte JM, Wright IJ, Reich PB, Aerts R (2009) A global study of relationships between leaf traits, climate and soil measures of nutrient fertility. Glob Ecol Biogeogr 18:137-149. doi:10.1111/j.1466-8238.2008.00441.x

50. Pennings SC, Paul V (1992) Effect of Plant Toughness, Calcification, and Chemistry on Herbivory by Dolabella auricularia. Ecology 73:1606-1619. doi:10.2307/1940014

51. Pereira JA, Londe V, Ribeiro SP, Sousa HC (2016) Crown architecture and leaf anatomic traits influencing herbivory on Clethra scabra Pers.: comparing adaptation to wetlands and drained habitats. Brazilian Journal of Botany 1:1-10. doi:10.1007/s40415-016-0343-2

52. Pérez-Harguindeguy $\mathrm{N}$ et al (2013) New handbook for standardized measurement of plant functional traits worldwide. Aust J Bot 61:167-234. doi:10.1071/BT12225 
53. Poorter L, Kitajima K, Mercado P, Chubina J, Melgar I, Prins HHT (2010) Resprouting as a persistence strategy of tropical forest trees: relations with carbohydrate storage and shade tolerance. Ecology 91:2613-2627. doi:10.1890/09-0862.1

54. Prentice IC, Cramer W, Harrison SP, Leemans R, Monserud RA, Solomon AM (1992) A global Biome model based on plant physiology and dominance, soil properties and climate. J Biogeogr 19:117134. doi:10.2307/284599

55. Price PW (1991) The plant vigor hypothesis and herbivore attack. Oikos 62:244-251. doi:10.2307/3545270

56. R Core Team 2015. R: A Language and Environment for Statistical Computing. R Foundation for Statistical Computing. Available from URL: http://www.r-project.org/Vienna

57. Raij B, Andrade JC, Cantarella H, Andrade JC (2001) Análise química para avaliação da fertilidade de solos tropicais. Instituto Agronômico, Campinas

58. Randlkofer B, Jordan F, Mitesser O, Meiners T, Obermaier E (2009) Effect of vegetation density, height, and connectivity on the oviposition pattern of the leaf beetle Galeruca tanaceti. Entomol Exp Appl 132:134-146. doi:10.1111/j.1570-7458.2009.00872.x

59. Raubenheimer D, Simpson SJ (1997) Integrative models of nutrient balancing: application to insects and vertebrates. Nutr Res Rev 10:151-179. doi:10.1079/NRR19970009

60. Rhoades D, Cates RG (1976) Toward a general theory of plant antiherbivorechemistry. In: Wallace J, Mansell R, eds. Biochemical interactions between plantsand insects. Recent advances in phytochemistry. New York, NY, USA: AcademicPress 155-204

61. Ribeiro SP, Brown VK (2006) Prevalence of monodominant vigorous tree populations in the tropics: herbivory pressure on species in very different habitats. J Ecol 94:932-941. doi:10.1111/j.13652745.2006.01133.x

62. Ribeiro SP, Basset $Y$ (2007) Gall-forming and free-feeding herbivory along vertical gradientes in a lowland tropical rainforest: the importance of leaf sclerophylly. Ecography 30:663-672. doi:10.1111/j.2007.0906-7590.05083.x

63. Ribeiro SP, Borges PAV, Gaspar C, Melo C, Artur RM, Serrano ARM, Amaral J, Aguiar C, Genage A, Quartau JA (2005) Canopy insect herbivores in the Azorean Laurisilva forests: key host plant species in a highly generalist insect community. Ecography 28:315-330. doi:10.1111/j.09067590.2005.04104.x

64. Ribeiro SP, Braga AO, Silva CHL, Silva L, Fernandes GW (1999) Leaf polyphenols in brazllian Melastomataceae: sclerophylly, habitats, and insect herbivores. Ecotropica 5:137-146

65. Rodrigues PMS, Schaefer CEGR, Silva JO, Ferreira WGJ, Santos RM, Neri AV (2018) The influence of soil on vegetation structure and plant diversity in different tropical savannic and forest habitats. Journal of Plant Ecology 11:226-236. doi:10.1093/jpe/rtw135

66. Roeder AK, Behmer ST (2014) Lifetime consequences of food protein-carbohydrate content for an insect herbivore. Funct Ecol 28:1135-1143. doi:10.1111/1365-2435.12262 
67. Ruggiero PGC, Batalha MA, Pivello VR, Meirelles ST (2002) Soil-vegetation relationships in cerrado (Brazilian savanna) and semi deciduous forest, Southeastern Brazil. Plant Ecol 160:1-16. doi:10.1023/A:1015819219386

68. Schiestl FP, Kirk H, Bigler L, Cozzolino S, Desurmont GA (2014) Herbivory and floral signaling: phenotypic plasticity and tradeoffs between reproduction and indirect defense. New Phytol 203:257266. doi:10.1111/nph.12783

69. Schlinkert H, Westphal C, Clough Y, László Z, Ludwig M, Tscharntke T (2015) Plant Size as Determinant of Species Richness of Herbivores, Natural Enemies and Pollinators across 21 Brassicaceae Species. PLoS One 10:1-18. doi:10.1371/journal.pone.0135928

70. Shaw DC, Ernest KA, Rinker HB, Lowman MD (2006) Stand-level herbivory in an old-growth conifer forest canopy. Western North American Naturalist 66:473-481. doi:10.3398/1527-0904

71. Silva JO, Espirito-Santo MM, Morais HC (2015) Leaf traits and herbivory on deciduous and evergreen trees in a tropical dry forest. Basic Appl Ecol 16:210-219. doi:10.1016/j.baae.2015.02.005

72. Silva LVC (2001) Diagnóstico da cobertura vegetal. Contribuição ao Plano de Manejo do Parque Estadual do Rio Doce. Projeto Doces Matas. Relatório Técnico

73. Silveira FAO, Negreiros D, Barbosa NPU et al (2015) Ecology and evolution of plant diversity in the endangered campo rupestre: a neglected conservation priority. Plant Soil 403:129-152. doi:10.1007/s11104-015-2637-8

74. Silvertown J, Dodd M (1996) Comparing plants and connecting traits. Philosophical Transactions: Biological Sciences 351:233-1239. doi:10.1098/rstb.1996.0106

75. Spawton KA, Wetzel WC (2015) Gall-Insect community on big sagebrush varies with plant size but not plant age. Environ Entomol 4:1095-1101. doi:10.1093/ee/nvv087

76. Strauss SY, Conner JK, Rush SL (1986) Foliar herbivory affects floral characters and plant attractiveness to pollinators: implications for male and female plant fitness. Am Nat 147:1098-1197

77. Sultan SE (2000) Phenotypic plasticity for plant development, function and life history. Trends Plant Sci 5:537-542. doi:10.1016/s1360-1385(00)01797-0

78. Violle C, Navas M, Vile D, Kazakou E, Fortunel C, Hummel H, Garnier E (2007) Let the concept of trait be functional! Oikos 116:882-892. doi:10.1111/j.0030-1299.2007.15559.x

79. Zvereva EL, Kozlov M (2014) Effects of herbivory on leaf life span in woody plants: a meta-analysis. J Ecol 102:873-881. doi:10.1111/1365-2745.12252

80. Zvereva EL, Zverev V, Kozlov M (2014) High densities of leaf-tiers in open habitats are explained by host plant architecture. Ecol Entomol 39:470-479. doi:10.1111/een.12123

\section{Tables}

Tab. 1: Habitat summary, functional traits and herbivory levels (mean $\pm \mathrm{SE}$ ) of three Byrsonima species. Different letters indicate statistical differences between the variables. 


\begin{tabular}{|c|c|c|c|}
\hline & Byrsonima sericea & Byrsonima variabilis & Byrsonima subterranea \\
\hline Ecoregion & Atlantic Forest & Campo rupestre & Campo rupestre \\
\hline Habitat & Forest & Rocky Outcrop & White Sand \\
\hline Park & PERD & PEIT & PSOB \\
\hline Life history & Tree & Shrub & Sub shrub \\
\hline Height $(\mathrm{cm})$ & $5.22 \pm 1.25^{a}$ & $1.51 \pm 0.42^{b}$ & $0.28 \pm 0.04^{c}$ \\
\hline Trunk diameter $(\mathrm{cm})$ & $59.81 \pm 29.66^{a}$ & $27.49 \pm 13.45^{\mathrm{b}}$ & $8.81 \pm 3.07^{c}$ \\
\hline Growth unit (un) & $52.2 \pm 22.09^{a}$ & $21.88 \pm 4.48^{b}$ & $6.04 \pm 3.72^{c}$ \\
\hline Leaf density (un) & $482 \pm 218.48^{a}$ & $300 \pm 134.92^{\mathrm{a}}$ & $20 \pm 15.93^{b}$ \\
\hline Nitrogen (dag/kg) & $1.746 \pm 0.213^{\mathrm{a}}$ & $1.352 \pm 0.162^{b}$ & $1.034 \pm 0.097^{c}$ \\
\hline Potassium (dag/kg) & $0.339 \pm 0.085^{a}$ & $0.313 \pm 0.054^{\mathrm{a}}$ & $0.647 \pm 0.130^{b}$ \\
\hline Calcium (dag/kg) & $1.313 \pm 0.372^{\mathrm{a}}$ & $0.879 \pm 0.351^{b}$ & $1.267 \pm 0.377^{a}$ \\
\hline Magnesium (dag/kg) & $0.222 \pm 0.047^{a}$ & $0.090 \pm 0.028^{b}$ & $0.146 \pm 0.043^{c}$ \\
\hline Sclerophylly (mm) & $0.266 \pm 0.017^{a}$ & $0.471 \pm 0.033^{b}$ & $0.549 \pm 0.101^{c}$ \\
\hline Herbivory (\%) & $5.58 \pm 3.86^{a}$ & $3.50 \pm 1.80^{b}$ & $2.97 \pm 2.33^{b}$ \\
\hline
\end{tabular}

\section{Figures}




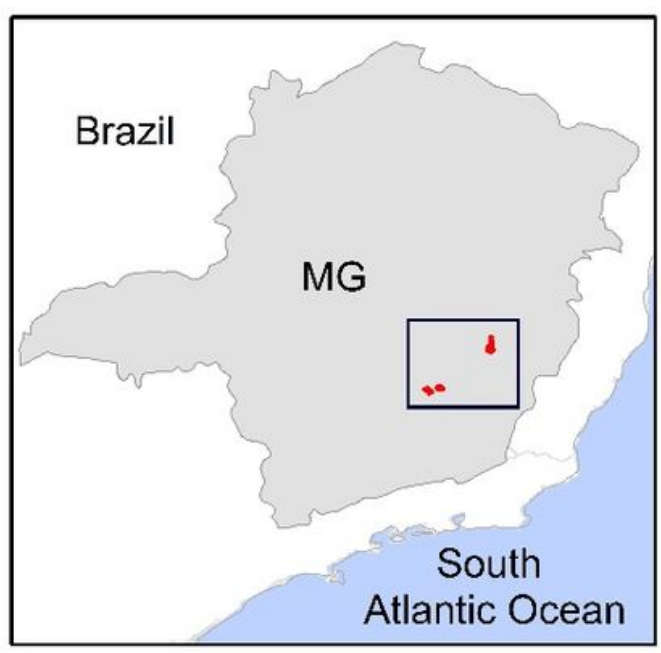

\section{Legend}

Serra do Ouro Branco State Park Itacolomi State Park

Rio Doce State Park

\section{Datum WGS 84}

Lat / log

Glória Ramos Soares (2019)

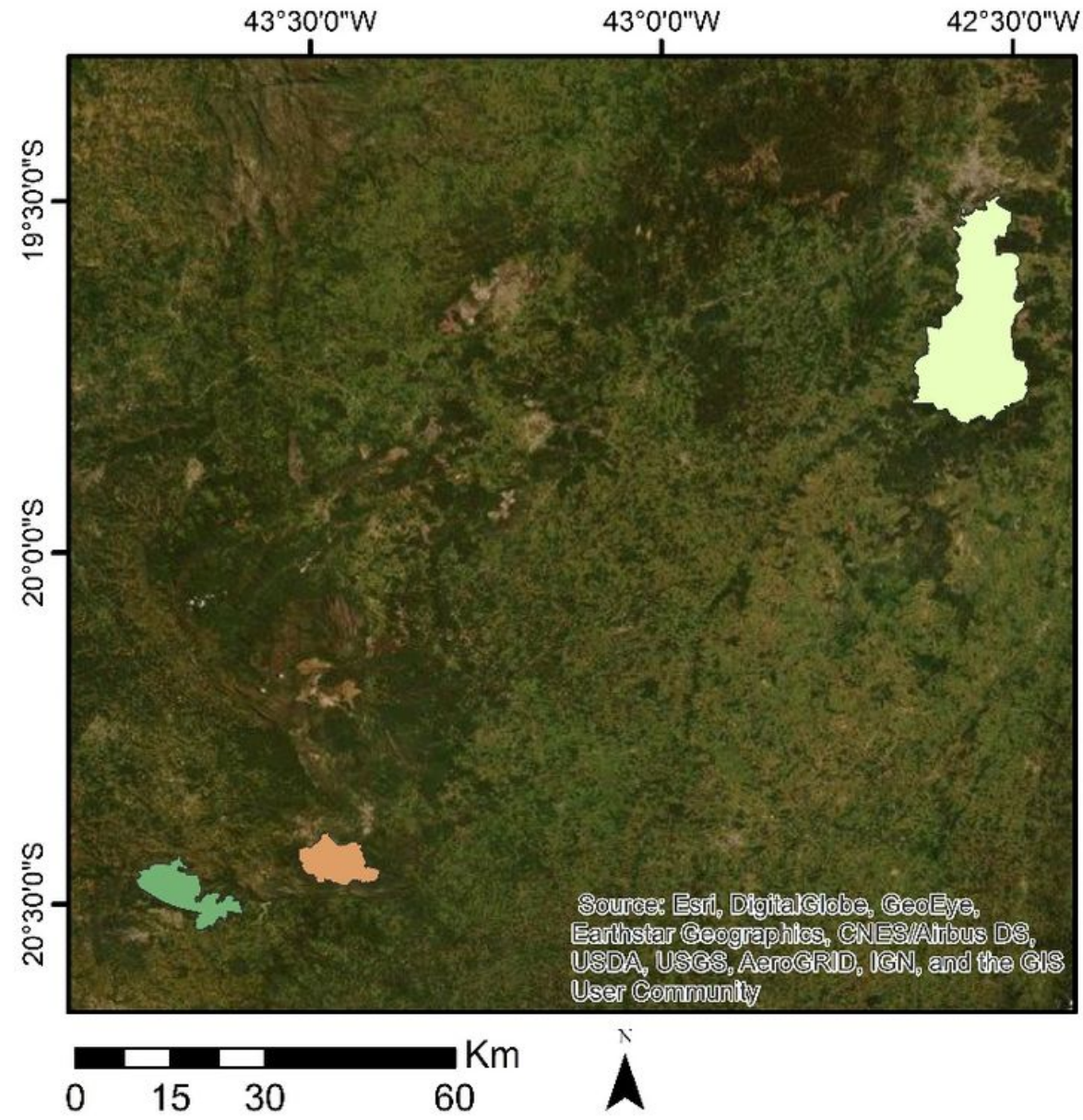

\section{Figure 1}

Map of the Doce River Basin in Minas Gerais, Brazil. The colors represent the different habitats. Note: The designations employed and the presentation of the material on this map do not imply the expression of any opinion whatsoever on the part of Research Square concerning the legal status of any country, territory, city or area or of its authorities, or concerning the delimitation of its frontiers or boundaries. This map has been provided by the authors. 


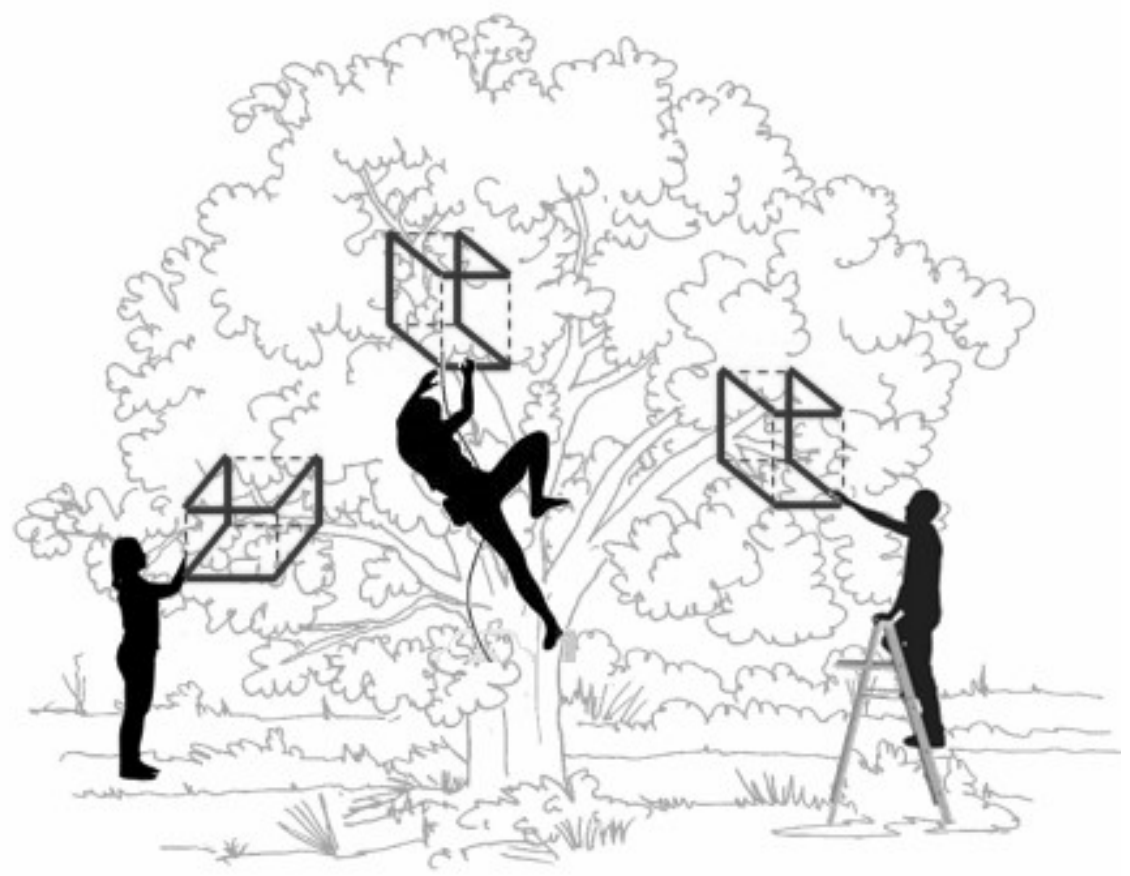

Figure 2

Schematic drawing of the cube methodology for herbivory sampling. Each cube was positioned in random parts of the crown to avoid collection bias. Art: Glória R. Soares. 

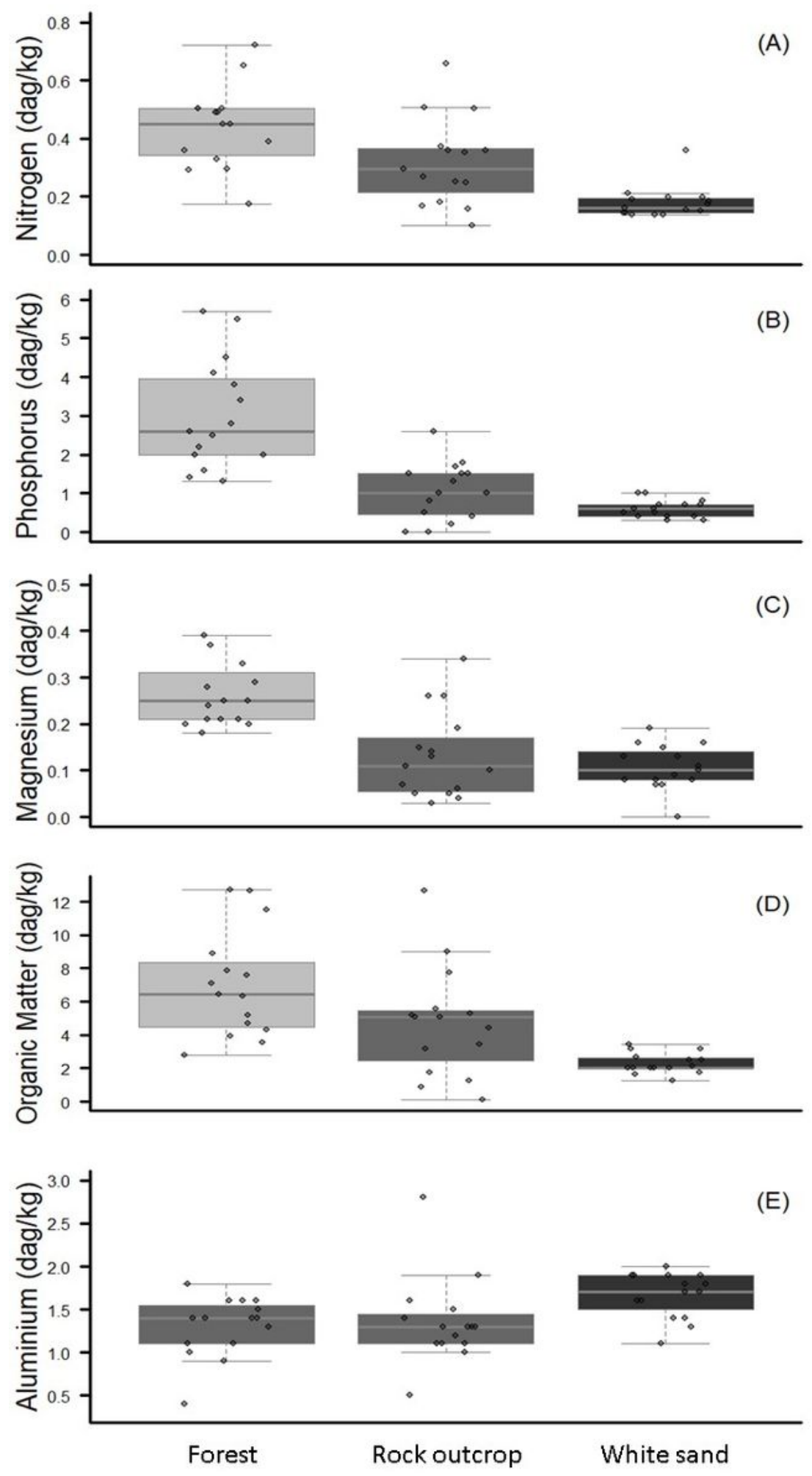

Figure 3

Concentration of soil chemical elements along the environmental gradient. (A) Nitrogen, (B) Phosphorus, (C) Magnesium, (D) Organic matter and (E) Aluminum. The colors of the boxplots represent differences between habitats. 

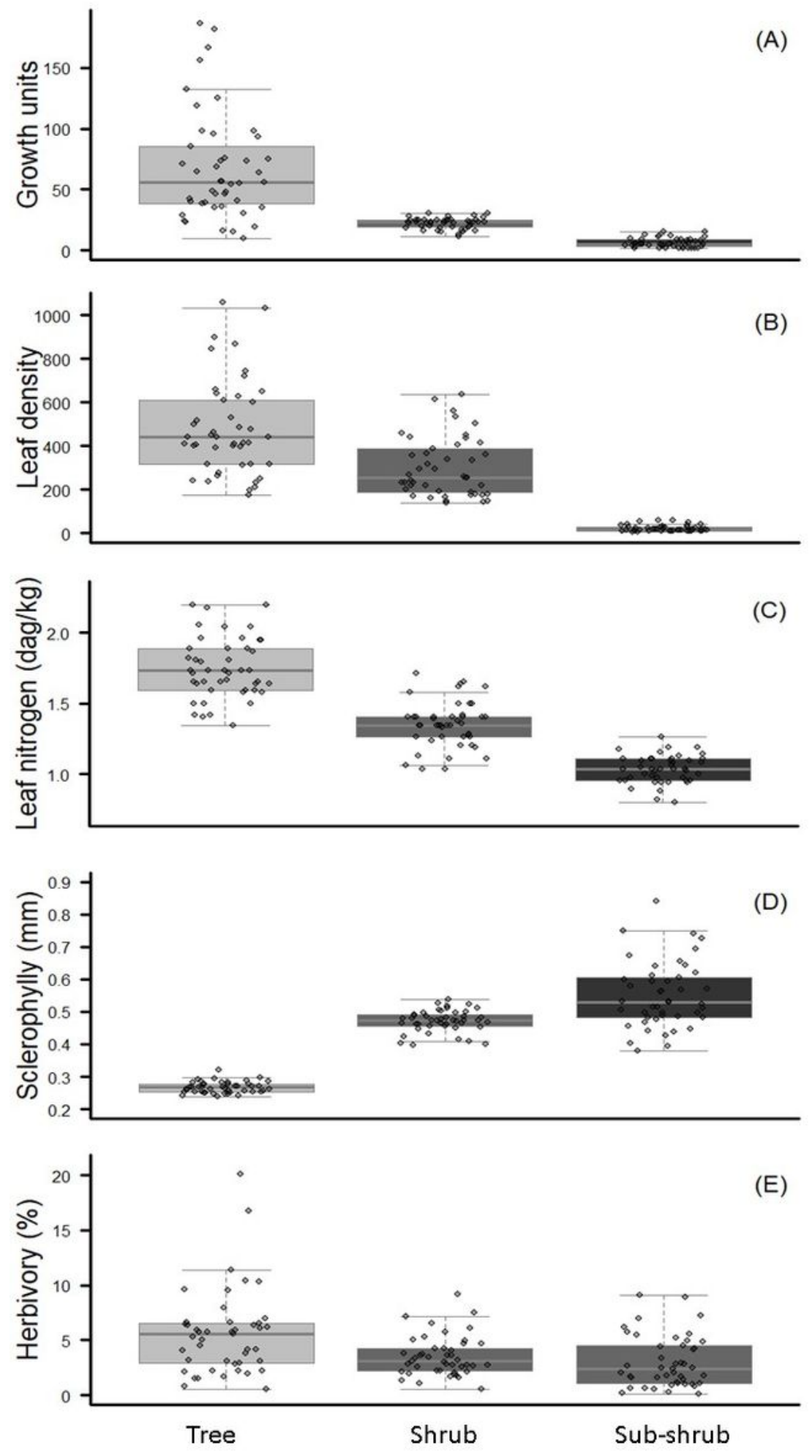

Figure 4

Differences among growth units (A), leaf density (B), leaf nitrogen (C), sclerophylly (D) and herbivory (E) in three plant species of different life forms. The colors of boxplots represent differences between habitats. 


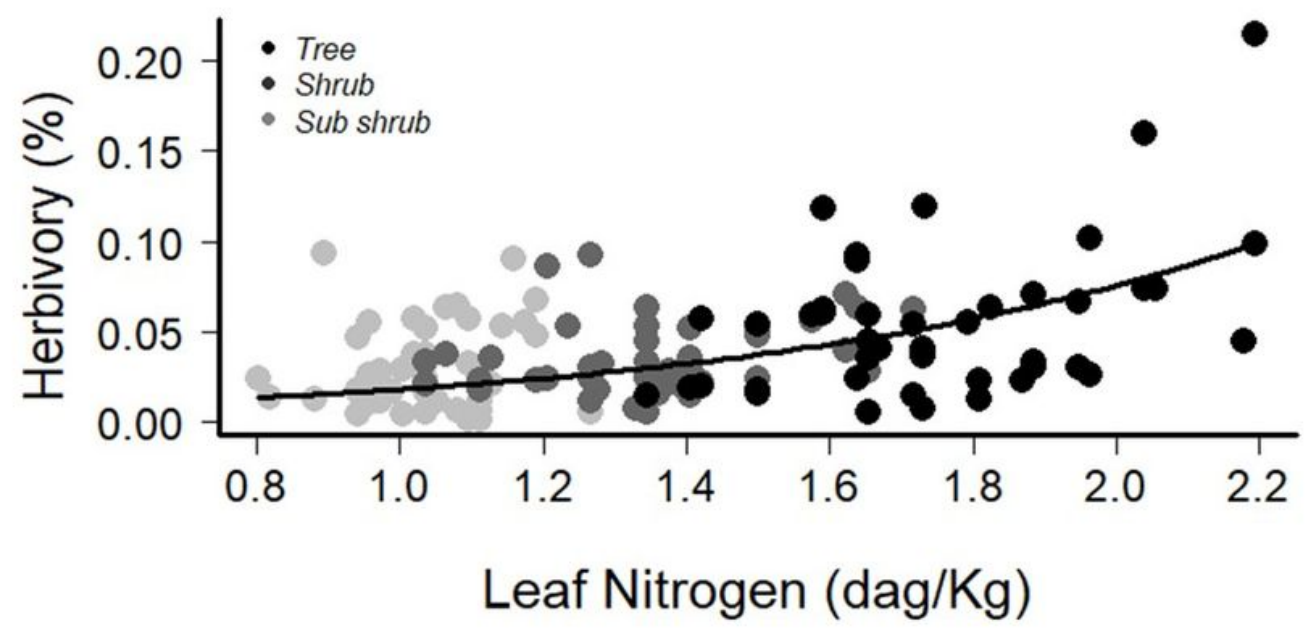

Figure 5

Effect of leaf nitrogen concentration on leaf area consumed in plants. Colors represent different life forms.
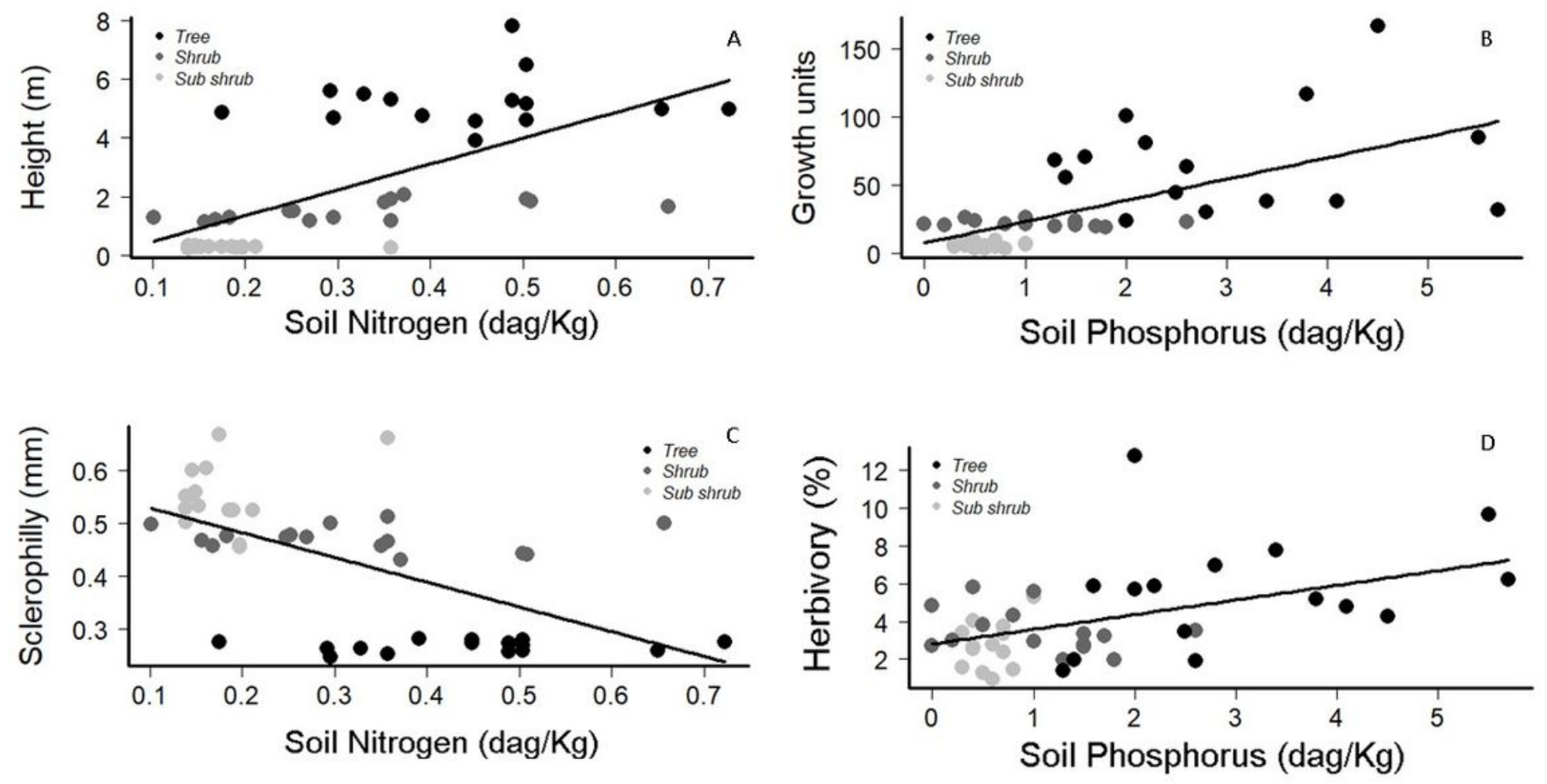
Figure 6

Effect of soil nutrient availability on (A) plant height, (B) growth units, (C) sclerophilly and (D) herbivory levels in different life forms. Colors represent different life forms. 